\title{
Analysis of Educational Status and Policy of SW Central University
}

\author{
Yoon-Su Jeong ${ }^{1}$ and Akash Kumar Bhoi ${ }^{2}$ \\ ${ }^{1}$ Division of Information and Communication Convergence Engineering, Mokwon University, 88 Doanbuk-ro, \\ Seo-gu, Daejeon 35349, Korea \\ 2 Department of Electrical and Electronics Engineering, Sikkim Manipal Institute of Technology, Rangpo, India
}

\begin{abstract}
Background/Objectives: As the fourth industrial revolution recently emerged, Korea is attempting to cultivate SW specialists focusing on SW central universities. Methods/Statistical analysis: However, in order for universities and industry to cooperate with each other and coexist, it is necessary to conduct a preliminary survey on the status of SW education currently operating in universities and the direction of government policies. Findings: In this paper, we present the educational status of the SW-centered college in order to find out the problem and solution of the SW curriculum which is currently operated by SW central university. In addition, this paper analyzed the present state and policy of SW education in university so as to maintain the win-win relationship between SW education of university and national policy. Improvements/Applications: In this paper, the contents of the SW education curriculum that the industry (consumer) needs are included based on the problems of the existing SW education, and the solutions and policies of the SW education related to the 4th industry.
\end{abstract}

\section{Index Terms}

Software, IT, Education, University, Tools.

\footnotetext{
Corresponding author : Yoon-Su Jeong

bukmunro@gmail.com

- Manuscript received August 3, 2017.

- Revised August 17, 2017; Accepted September 1, 2017.

- Date of publication September 30, 2017.

(c) The Academic Society of Convergence Science Inc.

2546-1583 $\odot 2017$ IJEMR. Personal use is permitted, but republication/redistribution requires IJEMR permission.
} 


\section{INTRODUCTION}

As the 4th industrial revolution has emerged, there has been an increasing demand for SW education for the development of high-level and convergent SW human resources reflecting the desperate needs of industrial sites [1,2]. In particular, we are building new tools out of the tools of existing educational system, centering on universities that are carrying out SW related education. At present, there is an urgent need for efforts to spread SW education at universities beyond the departments of universities. Therefore, universities should create win-win relationships (or cooperation) with industry to organize SW education as well as SW education to students. However, in order to improve the university SW education more than the existing one, comprehensive SW support reform plan should be prepared at the government level rather than smallscale support at the university level $[3,4]$.

University SW education should be used as a tool for students to solve problems creatively instead of simply training SW development skills [5-8]. SWcentered universities in Korea operate educational programs that can not be easily imitated in other subjects because students actively participate in the training.

In recent years, college students have been investigated to learn and enjoy expertise more actively than their passive counterparts [9-15]. SW learning in college is more effective than SW learning by inducing lessons to make and organize rather than just listening and listening in writing. For students who are taking SW education, SW education requires a new approach to define and reinvent the concept by oneself rather than infusion education [16-18].

In this paper, we analyze the educational status of SW - centered universities and propose educational policies and policies to train SW personnel in universities in the future. The proposed method analyzes the present status and policy of SW education in university so as to maintain the win win relationship between SW education and national policy of university. The proposed method is based on the problems of the existing SW education and includes the contents that can be derived from the SW course of the industry (consumer). However, the university SW curriculum has many changes according to the requirements of the industry (consumer) and the national policy. Therefore, SW education programs and policies are being developed focusing on SW education related to the fourth industry.

The composition of this paper is as follows. In Chapter 2, we will discuss the concept and operating principles of SW-centered universities. In Chapter 3, we propose the educational status at SW central university. In Chapter 4, we describe educational policy of SW central university. Finally, we conclude in Chapter 5.

\section{BACKGROUND}

\section{A. SW Central University}

SW Central University means university where SW education is spread by strengthening SW competitiveness of college students by turning university education to SW center [6,19-21]. Universities selected as SW central university are reorganizing their curriculum by reorganizing or expanding the number of related departments. SW universities newly selected as universities all have colleges and universities. Some universities are also changing the admission process of freshmen to promote $\mathrm{SW}$-centered universities $[3,13]$.

SW central university should be able to release SW talents that can revolutionize SW education in a short period of time. In order to meet these requirements, it is necessary to continuously expand SW-centered universities $[15,18,20]$.

\section{B. Operating Principles}

In order to overhaul the SW curriculum reflecting the requirements of the industrial field I) Base composition and SW environment improvement, II) All SW major students are required to participate in program management, III) selective participation programs [1,9].

Fig. 1 shows the new SW education program that SW central university should deal with through current problems by classifying the operating principle of SW central university into curriculum and education system.

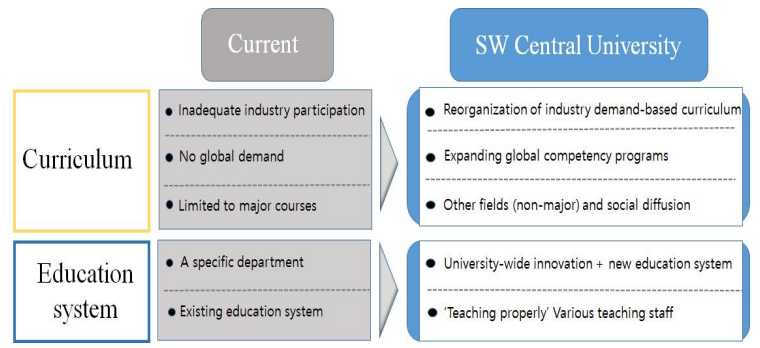

Fig. 1. Principle of operation of SW central university

The principles of foundation and environmental improvement management principles of the SW central university should be formed by the university and the enterprise in collaboration with the SW curriculum innovation committee. In addition, active involvement of companies and reinforcement of SW practice are among the most important items. For an innovative reorganization of existing departments that are carrying out SW education at university i) 
based on more than 100 students of SW major students per grade, ii) efforts to expand SW major, iii) SW education innovation should be promoted step by step in consideration of the ratio of SW specialists [14]. In addition, the university has a faculty member (including lecture specialist / industry academy professor) who has educational competence and practical experience, and it is necessary to provide incentives to excellent teachers [7]. In order to expand the SW education, it is necessary to propose a plan to improve the education / practice environment and to strengthen the practice of the open-source SW-type project. However, there is a problem that university students who take SW education are obliged to participate in practical industry-university cooperation project [6].

In the selective participatory program operation, the company operates a long-term internship (over 6 months) linked to participating companies, and interna- tional internship and training expansion are being conducted $[2,21]$.

\section{Education Status OF SW CENTRAL UNIVERSITY}

\section{A. Reorganization of the curriculum reflecting the needs of the industrial field}

In order to develop and operate a revolutionary SW curriculum required in the industrial field, the university SW curriculum needs to be revamped, focusing on the contents required in the industrial field [6]. However, the SW curriculum currently being operated by SW Central University is trying to reflect the requirements of the industry, but it does not adequately satisfy the SW curriculum required in the industrial field [13].

SW schools in Korea nationwide have been expanding SW education centered on practical capacity building education [16]. In particular, while reorganizing university SW education into a problem - solving curriculum, universities define the problems that SW industry needs and the knowledge to solve them. In addition, SW center university has established environment similar to the actual industrial site in the university, and uses the same tools used in the industrial field to conduct class and practice [4].

In the university, when SW major is involved in the project, the participating companies are allowed to acquire practical experience with SW majors through an internship program (more than 6 months) and carry out a training course linking with recruitment of industry after graduation $[5,16]$.

To activate SW education at SW central university, both universities and companies need a role that can coexist. In college, SW major must support the operation of a bachelor's degree, such as credits for long-term internships. In the case of universities, if the project in which the SW major is highly likely to be commercialized for innovation is promoted, the university can improve the quality of the SW education without any additional effort by promoting the enrichment program such as R \& D [7].

SW Central University is improving the quality of SW education through various incentive programs and innovative incentives such as employment security [15-19]. Some SW universities are integrating with similar departments to reflect industry requirements. In particular, some universities that reflect the requirements of industrial sites reflect the increase in the number of SWs and the proportion of SW specialists in the evaluation [11].

SW Central University should develop and operate more diverse programs to train SW specialists required in the global market. In the global market, in order for SW major students to perform their jobs smoothly, English education should be strengthened in addition to SW major knowledge $[5,6]$.

\section{B. Cultivating convergent talent with knowledge of other major fields and SW skills}

University SW basic education that can easily participate in all affiliates within the university should be spread. The university has been conducting the on-line and off-line SW basic curriculum during the winter vacation before admission to the freshman, and accepting it as a credit after completion [8]. In addition, some universities operate training programs and training programs in accordance with the characteristics of each major (humanity / society / engineering, etc.). The university's SW education has been promoting SW basic education centering on SW-centered universities in promoting the capacity of computing thinking [12].

Table 1 shows an example of the SW courses for non-majors at Sejong University in 2017, separated by preliminary university and SW foundation.

Table 1. Operating STATUS BY Year

\begin{tabular}{ccccc}
\hline \hline \multirow{2}{*}{$\begin{array}{c}\text { Divis } \\
\text { ion }\end{array}$} & \multicolumn{3}{c}{ Year } & Etc \\
\cline { 2 - 4 } & 2014 & 2015 & 2016 & \\
\hline Open & Understa & Understa & Understa & Acceptance \\
Cour & nding & nding & nding & of credits \\
se & computer & program & Program & after \\
& language & ming & ming -P & enrollment (B \\
& & & Understa & or more \\
& & & nding & credits) \\
& & & Advance & Improvement \\
& & & do learn \\
& & & Program & programming \\
& & & ming -C & languages \\
& & & Understa & that are \\
& & & nding & highly \\
& & & Advance & utilized in the \\
\hline
\end{tabular}




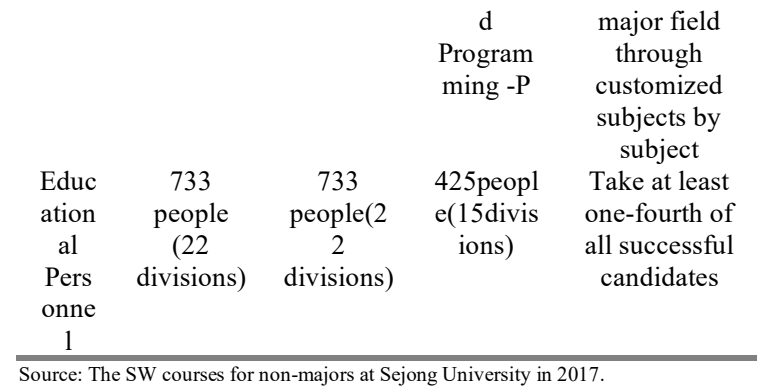

\section{Supporting the spread of $S W$ education}

In order to expand and operate SW education, SW central university has set up separate selection criteria such as the establishment of SW specialists and improved the SW development competency curriculum [17]. SW-centered universities should reflect the contribution of SW education to the SW education [19].

As shown in Fig. 2, SW education is also developing and running MOOC courses for SW students as well as simple video lectures for current students $[1,6]$. In order to spread SW education innovation through SW-centered university council, it is necessary for universities and companies to work together to create synergy effect of SW education $[3,14,21]$.

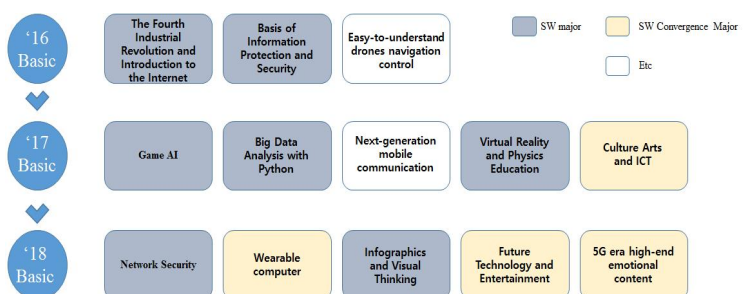

Fig. 2. Development and operation of MOOC course in SW field

\section{Educational Policy of SW Central University}

\section{A. Major policies and actions prior to 2016}

In order to promote SW education before 2016, the government suggested the importance of SW education and plans for implementing SW education in the future through the activation plan of SW education $[3,13]$.

Table 2. SW EDUCATION RELATED CONTENTS In 2015 REVISION CURRICULUM

\begin{tabular}{|c|c|c|c|}
\hline & \multirow[b]{2}{*}{ Reform plan } & \multirow[b]{2}{*}{ Major Reorganization Direction } \\
\hline Division & Current & & \\
\hline $\begin{array}{c}\text { Elementary } \\
\text { School } \\
\left(194 \frac{4}{4} \sim\right) \\
\end{array}$ & $\begin{array}{l}\text { ICT Unit in } \\
\text { Practice (12 times) }\end{array}$ & $\begin{array}{l}\text { Conduct Sw basic training } \\
\text { in the classroom (more } \\
\text { than } 178 \text { hours) }\end{array}$ & $\begin{array}{l}\text {-Problem solving process, algorithm, } \\
\text { programming experience } \\
\text { - Raising awareness of information ethics }\end{array}$ \\
\hline $\begin{array}{l}\text { Middle School } \\
\text { ('18년 } \sim)\end{array}$ & $\begin{array}{l}\text { Information Subject } \\
\text { (Optional Subject) }\end{array}$ & $\begin{array}{l}\text { More than } 34 \text { hours of } \\
\text { ifformation courses } \\
\text { (Required subject) }\end{array}$ & $\begin{array}{l}\text { - Implementation of problem solving based on } \\
\text { computing } \\
\text {-Simple algorithm, programming developmen }\end{array}$ \\
\hline $\begin{array}{l}\text { High School } \\
\text { ('18년 } \sim)\end{array}$ & $\begin{array}{l}\text { Information Subject } \\
\text { (Advanced Electives) }\end{array}$ & $\begin{array}{c}\text { Information course } \\
\text { (General elective courses) }\end{array}$ & $\begin{array}{l}\text {-Algorithm program design by merging with } \\
\text { various fields }\end{array}$ \\
\hline
\end{tabular}

As shown in Table 2, the government proposed a specific management plan for SW education to be applied at the school site through the SW education operation guidelines, and implemented a pilot project for SW education in the field of research schools and leading schools $[6,9]$.

\section{B. Revitalization of SW education for establishment of SW formal education base}

In order to establish SW formal education base, SW-centered university has been carrying out training for university professors every year for strengthening SW education capacity [13]. However, strengthening the SW education capacity is necessary not only for college professors but also for elementary and secondary education personnel.

In order to strengthen the education of elementary education SW by 2017, the Ministry of Education carried out job training for teachers and deepened training for about 6,000 teachers $[9,17]$.

Table 2 examines middle school information and computer education personnel from 2017 to 2020 according to the basic plan for software education activities of the Ministry of Education [16].

Table 3. Units for Magnetic Properties (Short Title Here) THE Plan FOR SECURING THE PROVINCIAL OFFICE OF EDUCATION ACCORDING TO THE PRELIMINARY ORGANIZATION OF THE 3-YEAR CURRICULUM OF THE FIRST GRADE IN 2006 (UNIT: PERSONS)

\begin{tabular}{|c|c|c|c|c|c|c|c|}
\hline \multirow{2}{*}{$\begin{array}{c}\text { Middle } \\
\text { school } \\
\text { information } \\
\text { computer }\end{array}$} & \multicolumn{5}{|c|}{ Division(Year) } & \multirow[b]{2}{*}{ Rate } & \multirow[b]{2}{*}{ Etc } \\
\hline & ‘17 & $' 18$ & ‘19 & ' 20 & Total & & \\
\hline $\begin{array}{l}\text { Need to } \\
\text { secure a } \\
\text { quorum }\end{array}$ & 39 & 194 & 186 & 113 & 532 & & \\
\hline $\begin{array}{c}\text { New } \\
\text { recruitment }\end{array}$ & 72 & 87 & 88 & 59 & 306 & $49.5 \%$ & \\
\hline $\begin{array}{c}\text { Double } \\
\text { majour } \\
\text { training }\end{array}$ & 0 & 39 & 36 & 25 & 100 & $16.2 \%$ & \\
\hline Etc & 3 & 80 & 77 & 52 & 212 & $34.3 \%$ & $\begin{array}{c}\text { MINOR } \\
\text { STUDY } \\
\text { AND } \\
\text { TRAINING }\end{array}$ \\
\hline Sum & 75 & 206 & 201 & 136 & 618 & & \\
\hline
\end{tabular}
Software Education

As shown in Table 3, it is possible to reinforce SW professionalism for freshmen entering SW-centered universities by strengthening and improving current pre-service teacher training course as SW education and programming-oriented curriculum.

\section{SW Education Policy of Ministry of Education}

The University has expanded SW education research and has developed a realistic curriculum by introducing the latest technologies (IoT, Incremental Reality, Big Data, etc.) that have been recently published [14]. The university develops and operates an intelligent learning analysis platform that 
evaluates the learning activities of SW majors and provides personalized learning diagnoses tailored to individual students.

\section{SW education policy for intelligence information society}

Recently, the Ministry of the Future announced in 2016 year that it will establish a mid- and long-term national strategy to prepare for the arrival of intelligence information society [21]. This presentation includes opinions of related ministries and experts considering the economic and social changes that may occur when entering the intelligence information society, and includes mid- to long-term policy directions and tasks to be implemented until 2030 [6]. The Ministry of Education plans to release intelligent information gifted students to about 5,000 people every year from $2020[19,20]$.

\section{Conclusion}

Recently, the University has been focusing on training software developers who are required by industry to improve the employment rate of graduates. In this paper, we analyze the educational status of SW - centered universities and analyze educational policies and policies to cultivate SW human resources. In this paper, we have developed SW education curriculum which is needed by the industry to maintain the win - win relationship between the SW education of the university and the national policy. In particular, since the university SW curriculum has many changes according to industry requirements and national policies, SW education programs and policies are being developed focusing on the SW education related to the 4th industry which has recently become an issue. In future research, we plan to develop SW-centered curriculum that can train various SW developers based on this research.

\section{ACKNOWLEDGMENT}

This work was supported by the Security Engineering Research Center granted by the Ministry of Trade, Industry and Energy.

\section{REFERENCES}

[1] World Economic Forum, The Future of Jobs-Employment, Skills and Workforce Strategy for the Fourth Industrial Revolution, 2016. World Economic Forum January.

[2] Yun, J. R. (2016). 4th Industrial Revolution and Soft Power, TTA Journal, 167, 4-7.
[3] Korea Institute for Curriculum and Evaluation. (2015). Introduction to the revised curriculum in 2015, Research Report CRC 2015-28.

[4] Ministry of Education. (2015). Practical Arts (Technology \& Home Economics) / Informatics Curriculum, Ministry of Education Notice 2015-74, 2015.

[5] Wing, J. M. (2006), Computational Thinking, Communication of the ACM, 49(3), 33-35.

[6] Ku, J. H. (2017). A Study on the Software Convergence Education for Non-Majors Computer Science using Creative Robot, Journal of the Korea Academia-Industrial Cooperation Society, 18(2), 631-638.

[7] Maeil Business News Korea. (2016). Career Analysis of 140 Global Venture CEOs, Maeil Business News Korea.

[8] TechTarget. (2016). What is software?, TechTarget.

[9] Committee on Information Technology Literacy. (1999), Being fluent with information technology, National Academy Press.

[10] Urban-Lurain, M., \& Weinshank D. J. (2000). Is There A Role for Programming in Non-Major Computer Science Courses?, Frontiers in Education Conference, FIE 2000 30th Annual.

[11] Carlisle, M. C., Wilson, T. A., Humphries, J. W., \& Hadfield, S. M. (2004). RAPTOR : Introducing Programming to NonMajors with Flowcharts, Journal of Computing Sciences in Colleges, 19(4), 52-60.

[12] Soloway, E. (1993). Should we teach students to program?, Communications of the ACM, 36(10), 21-24, 1993.

[13] Walker, H. M. (2015). Computational thinking in a nonmajors CS course requires a programming component, $A C M$ New York, 6(1), 58-61.

[14] Ministry of Science, ICT and Future Planning. (2015). Software oriented university promotion plan, Ministry of Science.

[15] Ministry of Science, ICT and Future Planning. (2016). Minister of Science, ICT and Future Planning-Software oriented university President Meeting Press release, Ministry of Science.

[16] Computer Science \& Engineering University of Washington. (2016). Non-Major Course Options, Computer Science \& Engineering University of Washington.

[17] Boston University Department of Computer Science. (2016). CS for Non-Majors, Boston University Department of Computer Science.

[18] Kim, J. O., \& Han, J. H. (2011). Action Plans of Green rLearning Services based on UCR(User Created Robots), Korea IT Service, 10(3), 21-30.

[19] Carnegie Melon University. (2016). Center for Computational Thinking, Carnegie Melon University.

[20] Rusk, N., Resnick, M., Berg, R., \& Pezalla-Granlund, M. (2008). New Pathways into Robotics: Strategies for Broadening Participation, Journal of Science Education and Technology, 1-10.

[21] Catlin, D., \& Woollard, J. (2014). Educational Robots and Computational Thinking, Proceedings of 4th International Workshop Teaching Robotics, Teaching with Robotics \& 5th International Conference Robotics in Education, 144-151. 